University of Nebraska - Lincoln

DigitalCommons@University of Nebraska - Lincoln

Biological Systems Engineering: Papers and

Publications

Biological Systems Engineering

$5-2012$

\title{
Fluidized-bed gasification of dairy manure by Box-Behnken design
}

Hanjing Wu

University of Nebraska-Lincoln, huansha2002@gmail.com

Milford A. Hanna

University of Nebraska-Lincoln, mhanna1@unl.edu

David D. Jones

University of Nebraska-Lincoln, david.jones@unl.edu

Follow this and additional works at: https://digitalcommons.unl.edu/biosysengfacpub

Part of the Biological Engineering Commons

Wu, Hanjing; Hanna, Milford A.; and Jones, David D., "Fluidized-bed gasification of dairy manure by Box-Behnken design" (2012). Biological Systems Engineering: Papers and Publications. 214.

https://digitalcommons.unl.edu/biosysengfacpub/214

This Article is brought to you for free and open access by the Biological Systems Engineering at DigitalCommons@University of Nebraska - Lincoln. It has been accepted for inclusion in Biological Systems Engineering: Papers and Publications by an authorized administrator of DigitalCommons@University of Nebraska Lincoln. 


\title{
Fluidized-bed gasification of dairy manure by Box-Behnken design
}

\author{
Hanjing Wu, ${ }^{1,2}$ Milford A. Hanna, ${ }^{1,2}$ and David D. Jones ${ }^{2}$ \\ 1. Industrial Agricultural Product Center, University of Nebraska- Lincoln, Lincoln, NE, USA \\ 2. Department of Biological Systems Engineering, University of Nebraska-Lincoln, Lincoln, NE, USA \\ Corresponding author - Milford A Hanna, Industrial Agricultural Product Center, University of Nebraska-Lincoln, \\ 211 L.W. Chase Hall, Lincoln, NE-68583, USA; email mhanna@unl.edu
}

\begin{abstract}
Application of excessive animal manure to the land may cause some environmental problems such as eutrophication of surface waters, degradation of ground water quality, and threats to human health. This paper reports an experimental study on the technology of biomass gasification to treat animal waste by analyzing the effects of key operating parameters on gasification. In this research, dairy manure from the University of Nebraska dairy farm was first collected and dried, and then gasified in a fluidized-bed, laboratory-scale gasifier to generate syngas. The effects of three parameters, namely temperature, steam to biomass ratio (SBR) and the equivalence ratio (ER), on the gasification were described by a Box-Behnken design (BBD). Results showed that increasing the temperature favored the formation of all three combustible gases, but the composition of each gas behaved differently according to the changing parameters. The lower heating value of the syngas varied from 2.0 to $4.7 \mathrm{MJ} \mathrm{m}^{-3}$, indicating gasification could be used as a waste management option to produce bioenergy, and potentially reduce problems associated with the disposal of animal waste.
\end{abstract}

Keywords: Dairy manure, fluidized bed gasification, manure management, syngas production, Box-Behnken design

\section{Introduction}

Animal manure is a carbon-rich substance commonly applied to crop fields as a source of organic fertilizer, and according to a United States Department of Agriculture (USDA) estimation, more than 335 million tons of manure waste is produced annually on farms in the United States (USDA Agricultural Research Service, 2006). However, manure may be transported to surface water and groundwater through runoff and infiltration, when applied in amounts greater than can be used by the soil (Campagnolo et al., 2002). Consequently, some new technologies have been proposed to treat animal waste, and one of them is gasification. With the purpose of converting the manure waste into clean fuel gas, gasification technology has been taken into account by some researchers as an alternative way to treat animal waste in nutrient and energy recovery strategies (Prapaspongsa et al., 2009).

The principle of biomass gasification is to produce syngas through the thermo-chemical conversion of biomass, usually involving partial oxidation of the feedstock in a reducing atmosphere in the presence of air, oxygen and/or steam (Li et al., 2004). The composition of the syngas is the result of a combination of a series of chemical reactions. The main reactions are (Ciferno and Marano, 2002; Franco et al., 2003):

$$
\begin{aligned}
2 \mathrm{C}+\mathrm{O}_{2} & =2 \mathrm{CO} \\
\mathrm{C}+\mathrm{O}_{2} & =\mathrm{CO}_{2} \\
\mathrm{C}+2 \mathrm{H}_{2} & =\mathrm{CH}_{4} \\
\mathrm{CO}+\mathrm{H}_{2} \mathrm{O} & =\mathrm{CO}_{2}+\mathrm{H}_{2} \\
\mathrm{CO}+3 \mathrm{H}_{2} & =\mathrm{CH}_{4}+\mathrm{H}_{2} \mathrm{O} \\
\mathrm{C}+\mathrm{H}_{2} \mathrm{O} & =\mathrm{CO}+\mathrm{H}_{2} \\
\mathrm{C}+\mathrm{CO}_{2} & =2 \mathrm{CO}
\end{aligned}
$$

Previous studies have investigated the application of gasification to treat animal waste. For example, Gordillo and Annamalai (2010) studied adiabatic fixed bed gasification of dairy biomass with steam and air. Young and Pian (2003) investigated the feasibility of integrating an advanced gasifier into the operation of a dairy farm for converting biomass wastes into fuel gas that can be used for power production. Research into fixed-bed gasification of feedlot manure and poultry litter biomass was conducted by Priyadarsan et al. (2004). However, less detailed information has been provided about the effects of operating conditions on syngas generated by animal manure. In the present study, dairy manure was gasified, and three key parameters were selected as the dependent variables: temperature, equivalence ratio (ER) and steam to biomass 


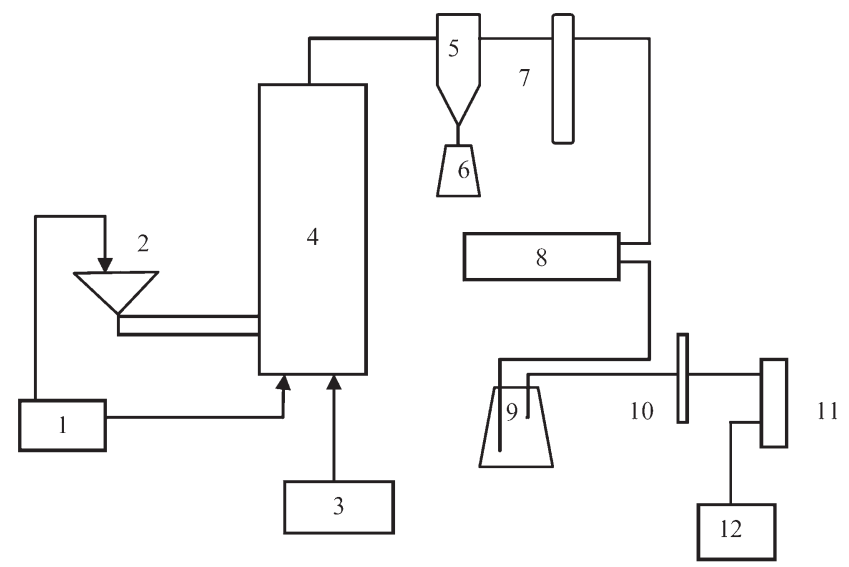

Figure 1. Schematic diagram of the fluidized-bed gasification system: 1 , air supply system; 2 , biomass feeder; 3 , steam generator; 4, fluidized-bed gasifier; 5, cyclone separator; 6, char collection vessel; 7 , high temperature filter; 8 , heat exchanger; 9 , condensation collection vessel; 10 , syngas filter; 11 , desiccator; 12 , gas collection bag.

ratio (SBR). Although the effects of some other parameters were analyzed in the previous gasification experiment, including the particle size of the biomass and secondary air injection (Li et al., 2004; Lv et al., 2004; Narvaez et al., 1996), these three parameters were considered as the most important variables that influenced chemical reactions in the gasifier. BoxBehnken Design (BBD) is a type of factional factorial designs, which is very efficient because of its smaller sample sizes (Haaland, 1989). Based on the principle of response surface methodology (RSM), BBD was applied to evaluate the effects of the above three factors on the syngas composition and energy efficiency of the gasification processes in this paper.

\section{Material and methods}

\section{Materials}

Fresh dairy manure collected from the University of Nebraska dairy farm was dried in the oven $\left(60^{\circ} \mathrm{C}\right)$ for 2 weeks, and then ground. After that, the moisture content, heating value, particle size distribution and ultimate analysis were conducted on the dried manure.

\section{Equipment}

The fluidized-bed gasification system is shown in Figure 1. The gasifier had two parts. The length of the lower part (bed) was $700 \mathrm{~mm}$ with an inside diameter of $3.81 \mathrm{~cm}$, and the length of the upper part (freeboard) was $500 \mathrm{~mm}$ with an inside diameter of $6.35 \mathrm{~cm}$. A data acquisition system (Model: NI SCXI-1102 with 32-channel thermocouple terminal block) and LabView 2009 (National Instruments Corporation, Austin, TX, USA) were applied to monitor the temperature at several locations throughout the gasification system.

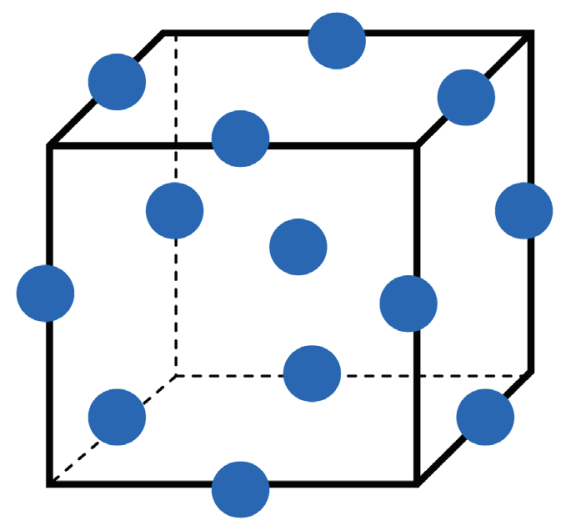

Figure 2. Geometry of a three factor BBD design.

\section{Operation}

At the beginning of the experiment, the fluidized bed was charged with $80 \mathrm{~g}$ of silica sand as the fluidized bed material, with the purpose of stabilizing fluidization and better heat transfer ( $\mathrm{Lv}$ et al., 2003). The gasifier was heated by a tube furnace made of black iron, and the saturated steam was superheated. After both of the gasifier temperature and steam temperature reached their predetermined set points, air was fed into the gasifier first, and then the manure samples were fed at a constant rate of $1.67 \mathrm{~kg} \mathrm{~h}^{-1}$. After 2 to $3 \mathrm{~min}$, when syngas was observed downstream, superheated steam was fed from the bottom of the gasifier. After another $5 \mathrm{~min}$, the syngas generated was collected in gas sample bags, and char was collected at the bottom of the cyclone separator (Kumar et al., 2009).

\section{Gas sampling and analysis}

For every experimental run, four sample bags were used. The composition of the syngas collected was analyzed by a gas chromatography system (Model: AutoSystem GC, PerkinElmer Inc., Waltham, MA, USA). As the syngas contained a very small amount of $\mathrm{NH}_{3}$ and $\mathrm{H}_{2} \mathrm{~S}$, the lower heating value (LHV) only took into account the $\mathrm{CH}_{4}, \mathrm{CO}$ and $\mathrm{H}_{2}$. This value was calculated by equation (8) (Kumar et al., 2009):

$$
\begin{aligned}
\text { LHV of syngas }\left(\mathrm{MJ} \mathrm{m}^{-3}\right)= & \left(35.81 \times \mathrm{CH}_{4}\right. \\
& \left.+12.62 \times \mathrm{CO}+10.71 \times \mathrm{H}_{2}\right)
\end{aligned}
$$

where $\mathrm{CH}_{4}, \mathrm{CO}$ and $\mathrm{H}_{2}$ were the volume fraction of each gas.

\section{Experimental design}

Box-Behnken designs (BBD) are experimental designs for response surface methodology, which explore the relationships between several explanatory variables and one or more response variables (Zhu et al., 2010). BBD consists of a central point and the middle points of the edges of the cube circumscribed on the sphere (Kumar et al., 2008). These designs are rotatable (or near rotatable) and require three levels of each factor, and the geometry of a three-factor BBD is shown in Figure 2 (Eriksson et al., 2008). In this experiment, a three- 
Table 1. Levels of three variables.

\begin{tabular}{lccc}
\hline Variables & Levels & & \\
\hline Coded level & -1 & 0 & 1 \\
Temperature $\left({ }^{\circ} \mathrm{C}\right)$ & 650 & 750 & 850 \\
ER & 0.08 & 0.14 & 0.20 \\
SBR & 0 & 0.88 & 1.76 \\
\hline
\end{tabular}

Table 2. The three-level three-factorial Box-Behnken design.

\begin{tabular}{lrrr}
\hline Exp no. & Temperature & ER & SBR \\
\hline 1 & -1 & -1 & 0 \\
2 & -1 & 1 & 0 \\
3 & 1 & -1 & 0 \\
4 & 1 & 1 & 0 \\
5 & -1 & 0 & -1 \\
6 & -1 & 0 & 1 \\
7 & 1 & 0 & -1 \\
8 & 1 & 0 & 1 \\
9 & 0 & -1 & -1 \\
10 & 0 & -1 & 1 \\
11 & 0 & 1 & -1 \\
12 & 0 & 1 & 1 \\
13 & 0 & 0 & 0 \\
14 & 0 & 0 & 0 \\
15 & 0 & 0 & 0
\end{tabular}

level, three-factor BBD was applied to investigate the gasification parameters affecting the syngas composition and energy efficiency during the whole process. The three variables were temperature, ER and SBR, and the latter two were defined as follows (Lv et al., 2004).

$$
\begin{aligned}
E R & =\frac{\text { weight air / weight dry biomass }}{\text { stoichiometric air / biomass ratio }} \\
\mathrm{SBR} & =\frac{\text { weight of steam }}{\text { weight of biomass }}
\end{aligned}
$$

The response values were $\mathrm{CH}_{4}, \mathrm{CO}, \mathrm{H}_{2}$, and energy efficiency, respectively; therefore, four models were established. Energy efficiency is defined by equation (11) (Rajvanshi, 1986).

$$
\text { Energy efficiency }=\frac{L V H_{\text {gas }} \times F}{D \times E}
$$

where $F$ is the flow rate of the syngas $\left(\mathrm{m}^{3} \mathrm{~min}^{-1}\right), L H V_{\mathrm{gas}}$ is the lower heating value of the syngas $\left(\mathrm{MJ} \mathrm{m}^{-3}\right), D$ is the flow rate of dairy manure $\left(\mathrm{kg} \mathrm{min}^{-1}\right), E$ is the LHV of dairy manure $\left(\mathrm{MJ} \mathrm{kg}^{-1}\right)$.

Three variables were equally spaced, and the low, middle, and high levels of each variable were coded as $-1,0$, and 1, respectively, as given in Table 1 . The experimental design is given in Table 2 (Annadurai and Sheeja, 1998; Kumar et al., 2007). For each experimental run, there were three replications.
Table 3. Properties of dried dairy manure sample.

\begin{tabular}{lr}
\hline Moisture content (\% wet basis ) & 7.78 \\
Ultimate analysis (\% wet basis) & \\
C & 35.21 \\
H & 4.07 \\
O & 27.35 \\
N & 1.48 \\
S & \\
0.234 & \\
Ash & 23.89 \\
Higher heating value $\left(\mathrm{MJ} \mathrm{kg}^{-1}\right)$ & 11.6 \\
Mean particle size $(\mathrm{mm})$ & 1.02 \\
\hline
\end{tabular}

\section{Statistical analysis}

The statistical software SAS 9.2 (SAS Institute Inc., Cary, NC, USA) was used to establish the quadratic model, and the statistical software MINITAB 14.1 (Minitab Inc., State College, PA, USA) was applied to define the response surface plots.

\section{Results and discussion}

\section{Characteristics of dairy manure}

Characteristics of dairy manure, including moisture content, ultimate analysis, heating value and mean particle size are shown in Table 3.

\section{LHV of syngas}

The LHV of the syngas generated by air and steam gasification of dairy manure ranged from 2.0 to $4.7 \mathrm{MJ} \mathrm{m}^{-3}$, which was lower than that of the syngas produced through oxygen gasification (oxygen as the gasification medium), which is usually more than $10 \mathrm{MJ} \mathrm{m}^{-3}$, due to nitrogen dilution (Ciferno and Marano, 2002). In addition, the value was lower than that of the syngas from pine sawdust (6.7 to $9.1 \mathrm{MJ} \mathrm{m}^{-3}$ ) ( $\mathrm{Lv}$ et al., 2004) and olive particles (10.9 to $13.1 \mathrm{MJ} \mathrm{m}^{-3}$ ) (Rapagnà et al., 2000), due to the relatively lower calorific value of dairy manure. However, this syngas can still be combusted to generate heat for steam or power generation (Priyadarsan et al., 2004), and Wang et al. (2009) pointed out that low heat-value syngas can be used in a combustor.

\section{Char content}

Amount of char separated by the cyclone varied 5 to $35 \mathrm{~g}$ in all experimental runs. As a byproduct of gasification, char was manufactured from biomass. Therefore char was high in carbon content and also contained a range of macro- and micronutrients (Lehmann and Joseph, 2009).

\section{Statistical model}

The four statistics models developed are listed in Table 4, where the coefficients of determination $\left(R^{2}\right)$ indicate the overall fit of the model, and the square root of the variance of the residuals (RMSE) measure the difference between the predicted and the observed value. 
Table 4. Statistic model for each response value.

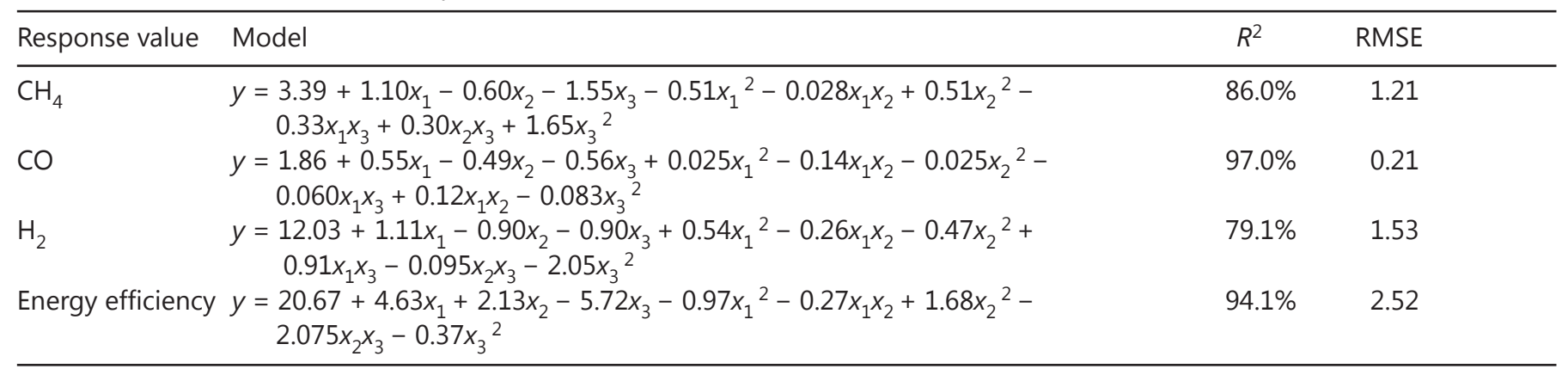

$x_{1}, x_{2}$ and $x_{3}$ are the coded value for temperature, ER and SBR, respectively (from Table 1 ). All of $x_{1}, x_{2}$ and $x_{3}$ are in the range of [-1, 1].
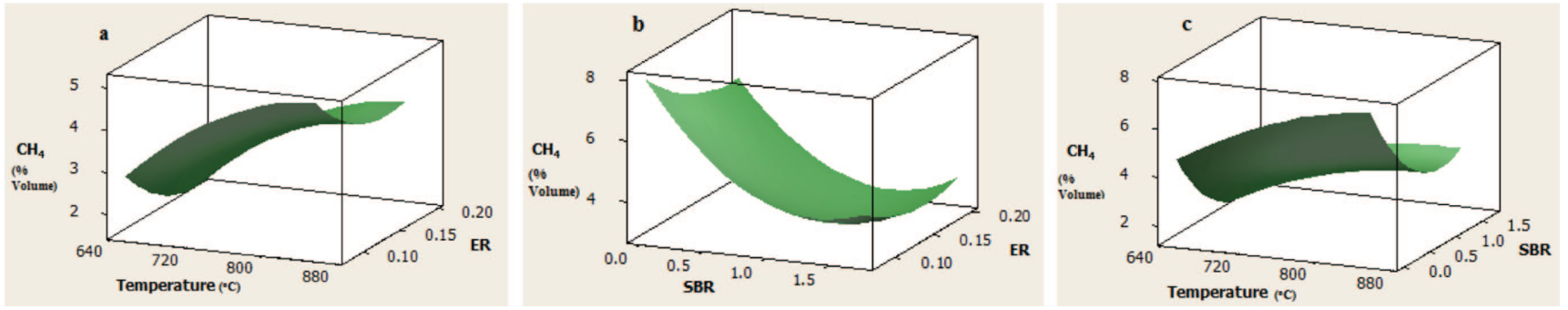

Figure 3. Influences of two parameters on $\mathrm{CH}_{4}$ yield, where in (a) $\mathrm{SBR}=0.88$, in (b) $T=750{ }^{\circ} \mathrm{C}$, and in (c) $\mathrm{ER}=0.14$.
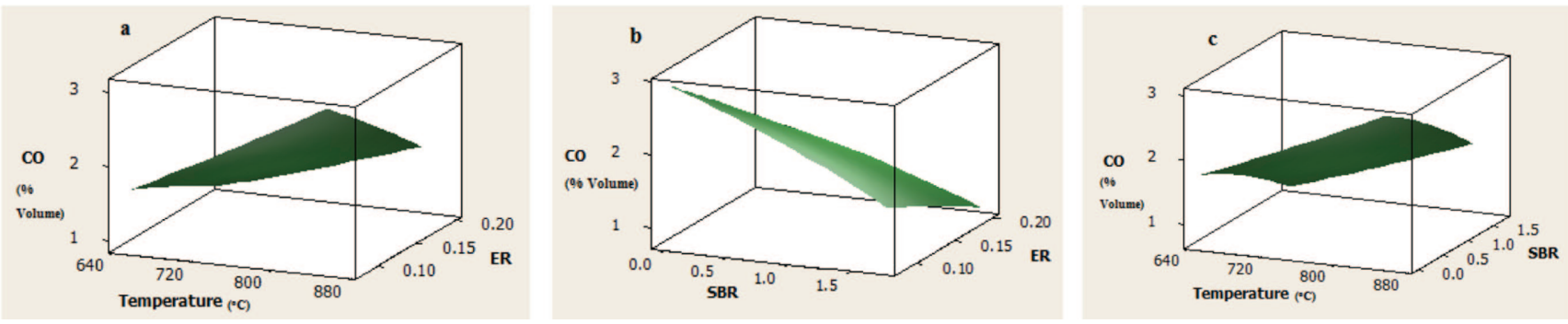

Figure 4. Influences of two parameters on $\mathrm{CO}$ yield, where in (a) $\mathrm{SBR}=0.88$, in (b) $\mathrm{T}=750^{\circ} \mathrm{C}$, and in (c) $\mathrm{ER}=0.14$.

\section{$\mathrm{CH}_{4}$ production}

The influences of two parameters on methane yield, while holding the third parameter at the middle value, are shown in Figure 3(a)-(c). From the plot, it can be seen that the range of methane generated by dairy manure gasification varied from 2 to $8 \%$. In Figure 3(b) and (c), with increasing SBR, the methane yield decreased first until the value of SBR reached around 1.4, after which the methane yield became stable. On the other hand, temperature and ER did not significantly influence the methane yield. Similar results were reported by Narvaez et al. (1996), who pointed out that the $\mathrm{CH}_{4}$ amount did not vary a lot when the gasification temperature increased from 700 to $850^{\circ} \mathrm{C}$.

\section{CO production}

The influences of two parameters on the CO yield, while holding the third parameter at the middle value, are shown in Figure $4(\mathrm{a})-(\mathrm{c})$. During gasification of dairy manure, not much $\mathrm{CO}$ was produced, which may have been due to the relatively low energy density of dairy manure. The $\mathrm{CO}$ concentration decreased significantly with the decreasing SBR shown in Figure $4(\mathrm{~b})$ and (c), the same trend was observed by Franco et al. (2003). Furthermore, the declining ER resulted in a increasing concentration of CO; this was explained by Turn et al. (1998) that as ER decreased, less fuel was converted into $\mathrm{CO}_{2}$ and $\mathrm{H}_{2} \mathrm{O}$, and steam gasification (reaction (6)) became more important, producing more $\mathrm{CO}$.

\section{$\mathrm{H}_{2}$ production}

The influences of two parameters on the $\mathrm{H}_{2}$ yield, while holding the third parameter at the middle value, are shown in Figure 5(a) to (c). From the plots in Figure 5(a) (c), an increasing trend of $\mathrm{H}_{2}$ concentration was observed when the gasification temperature was increased from 650 to $850{ }^{\circ} \mathrm{C}$. In another aspect, with the SBR rising from 0 to 0.8 , the $\mathrm{H}_{2}$ concentration increased from 10 to $14 \%$, after which, increasing SBR did not increase the $\mathrm{H}_{2}$ predication. The explanation may be that for a SBR lower than 0.8 , not enough steam reacted with all the biomass and reactions (4) (water-gas shift) and (6) (steamcarbon reaction) did not seem to reach a state of completion. Consequently, the concentration of $\mathrm{CO}$ decreased, and the 

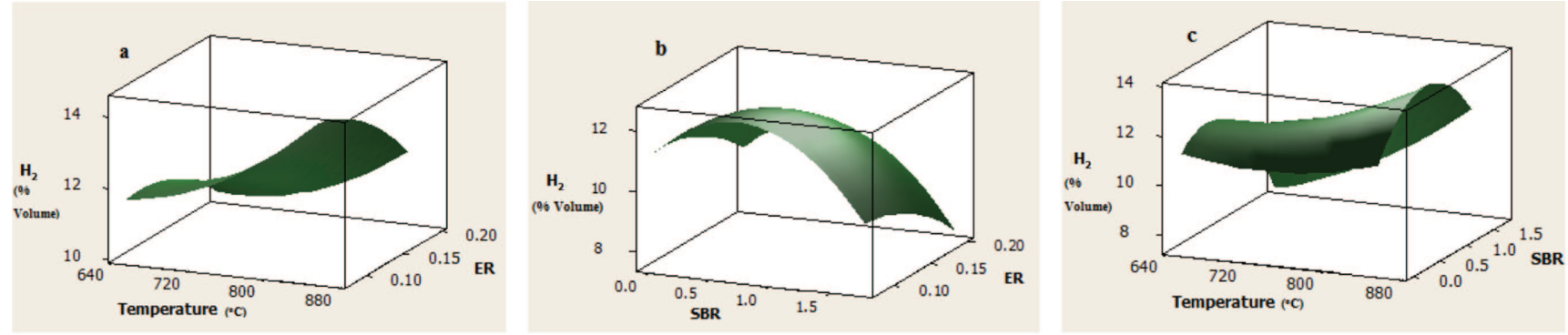

Figure 5. Influences of two parameters on $\mathrm{H}_{2}$ yield, where in (a) $\mathrm{SBR}=0.88$, in (b) $\mathrm{T}=750^{\circ} \mathrm{C}$, and in (c) $\mathrm{ER}=0.14$.
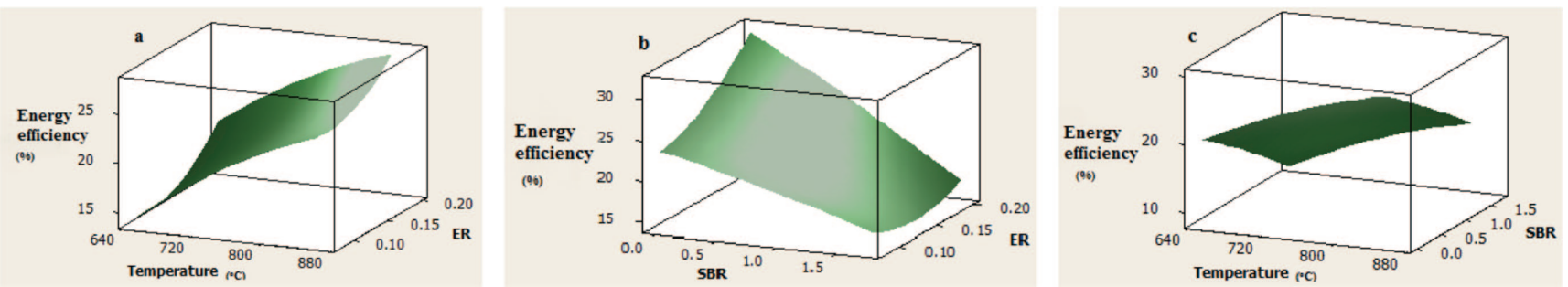

Figure 6. Influences of two parameters on energy efficiency, where in (a) $S B R=0.88$, in (b) $T=750^{\circ} \mathrm{C}$, and in (c) $E R=0.14$.

$\mathrm{H}_{2}$ concentration increased simultaneously. With the increasing steam input, the influencing reactions could reach a state of equilibrium, leading to the maximum value of $\mathrm{H}_{2}$ yield (Franco et al., 2003).

\section{Energy efficiency}

The influences of two parameters on the energy efficiency, while holding the third parameter at the middle value, are shown in Figure 6(a)-(c). Energy conversion efficiency of gasification of dairy manure (15 to $30 \%$ ) was lower than that of wood, which was about 60 to $70 \%$ (Ciferno \& Marano, 2002). It was interpreted that dairy manure had a relatively lower heating value than wood, and more ash content. It also showed that the temperature was the most influential factor with respect to the energy efficiency. Higher temperature favored the higher energy efficiency.

\section{Conclusions}

1. Dairy manure was successfully gasified in a laboratoryscale fluidized-bed gasifier, and the syngas was sampled and analyzed. In addition, a three-factorial BBD design was applied to evaluate the effects of three operating conditions (temperature, ER and SBR) on the syngas composition and energy efficiency of the gasification process.

2. As the temperature increased the combustible gas and energy efficiency also increased on the whole; however, the composition of each gas was also determined by the comprehensive effect of all operating parameters. In general, an increasing SBR (0 to 0.8) led to a decreasing $\mathrm{CH}_{4}$ concentration and an increasing $\mathrm{H}_{2}$ concentration, whereas the declining ER (2.0 to 0 ) resulted in a rising concentration of $\mathrm{CO}$.
3. Depending on the operating parameters, the LHV of the syngas varied from 2.0 to $4.7 \mathrm{MJ} \mathrm{m}^{-3}$. Although it is a low-heating value gas, some end-use applications can be taken into account. Experimental results suggest gasification could be used as a waste management option to reduce animal waste disposal problems in the USA.

\section{Funding}

This research received no specific grant from any funding agency in the public, commercial, or not-for-profit sectors.

\section{References}

Annadurai G and Sheeja RY (1998) Use of Box-Behnken design of experiments for the adsorption of verofix red using biopolymer. Bioprocess Engineering 18(6): 463-466.

Campagnolo ER, Johnson KR, Karpati A, et al. (2002) Antimicrobial residues in animal waste and water resources proximal to large-scale swine and poultry feeding operations. The Science of the Total Environment 299(1-3): 89-95.

Ciferno JP and Marano JJ (2002) Benchmarking biomass gasification technologies for fuels, chemicals and hydrogen production. Pittsburgh, PA, USA: NETT, US Department of Energy (DOE).

Ericksson L, Johansson E, Kettaneh-Wold N, et al. (2008) Design of Experiments, Principles and Applications, 3rd ed. Umeå, Sweden: Umetrics Academy.

Franco C, Pinto F, Gulyurtlu I, et al. (2003) The study of reactions influencing the biomass steam gasification process. Fuel 82(7): 835-842.

Gordillo G and Annamalai K (2010) Adiabatic fixed bed gasification of dairy biomass with air and steam. Fuel 89(2): 384-391. 
Haaland PD (1989) Experimental Design in Biotechnology. New York, USA: Marcel Dekker.

Kumar A, Prasad B, and Mishra IM (2007) Process parametric study for ethene carboxylic acid removal onto powder activated carbon using Box-Behnken design. Chemical Engineering and Technology 30(7): 932-937.

Kumar A, Prasad B, and Mishra IM (2008) Optimization of process parameters for acrylonitrile removal by a low-cost adsorbent using Box-Behnken design. Journal of Hazardous Materials 150(1): 174-182.

Kumar A, Eskridge K, Jones DD, et al. (2009) Steam-air fluidized bed gasification of distillers grains: Effects of steam to biomass ratio, equivalence ratio and gasification temperature. Bioresource Technology 100(6): 2062-2068.

Lehmann J and Joseph S (2009) Biochar for environmental management : Science and technology. London and Sterling, VA, USA: Earthscan.

Li XT, Grace JR, Lim CJ, et al. (2004) Biomass gasification in a circulating fluidized bed. Biomass and Bioenergy 26(2): 171-193.

Lv P, Chang J, Xiong Z, et al. (2003) Biomass air-steam gasification in a fluidized bed to produce hydrogen-rich gas. Energy and Fuels 17(3): 677-682.

Lv PM, Xiong ZH, Chang J, et al. (2004) An experimental study on biomass air-steam gasification in a fluidized bed. Bioresource Technology 95(1): 95-101.

Narvaez I, Orio A, Aznar MP, et al. (1996) Biomass gasification with air in an atmospheric bubbling fluidized bed. Effect of six operational variables on the quality of the produced raw gas. Industrial and Engineering Chemistry Research 35(7): 2110.

Prapaspongsa T, Poulsen TG, Hansen JA, et al. (2010) Energy production, nutrient recovery and greenhouse gas emission potentials from integrated pig manure management systems. Waste Management and Research 28(5): 411-422.
Priyadarsan S, Annamalai K, Sweeten JM, et al. (2004) Fixedbed gasification of feedlot manure and poultry litter biomass. Transactions of the ASAE (now Transactions of the ASABE) 47(5): 1689.

Rajvanshi AK (1986) Biomass gasification. In: Goswami DY (ed.) Alternative Energy in Agriculture. Boca Raton, FL, USA: CRC Press, pp. 83-102.

Rapagnà S, Kiennemann NJ, Kiennemann A, and Foscolo PU (2000) Steam-gasification of biomass in a fluidised-bed of olivine particles. Biomass and Bioenergy 19(3): 187-197.

Turn S, Kinoshita C, Zhang Z, et al. (1998) An experimental investigation of hydrogen production from biomass gasification. International Journal of Hydrogen Energy 23(8): 641-648.

USDA Agricultural Research Service (2006). FY-2005 Annual Report Manure and Byproduct Utilization. Retrieved from http://www.ars.usda.gov/research/programs/programs.

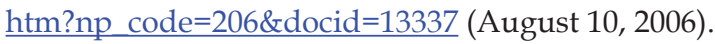

Wang L, Milford AH, Weller CL, et al. (2009) Technical and economical analyses of combined heat and power generation from distillers grains and corn stover in ethanol plants. Energy Conversion and Management 50(7): 1704-1713.

Young L and Pian CCP (2003) High-temperature, air-blown gasification of dairy-farm wastes for energy production. Energy 28(7): 655-672.

Zhu T, Heo HJ, and Row KH (2010) Optimization of crude polysaccharides extraction from Hizikia fusiformis using response surface methodology. Carbohydrate Polymers 82(1): 106-110. 